Kabul Tarihi: 09.05.2016

\title{
Turist Rehberlerinin Tükenmişlik Düzeylerinin İşe Yabancılaşma Eğilimlerine Etkisi
}

\section{The Impact of Burnout Levels of Tourist Guides on Their Work Alienation Tendencies}

\section{Ezgi KIRICI}

Nevşehir Hacı Bektaş Veli Üniversitesi

Sosyal Bilimler Enstitüsü

E-posta:ezgi.krc@windowslive.com
Yrd. Doç. Dr. Aziz Gökhan ÖZKoç

Nevşehir Hacı Bektaş Veli Üniversitesi

Turizm Fakültesi

E-posta: aziz.ozkoc@gmail.com

\section{Öz}

$\mathrm{Bu}$ araştırmanın amacı turist rehberlerinin işe yabancılaşma eğilimlerine etki eden tükenmişlik boyutlarını analiz etmek ve değerlendirmektir. Tükenmişlik ile işe yabancılaşma etkileşimine dair ortaya konulan teorik çerçeve temel alınarak geliştirilen üç araştırma hipotezinin çözümlenmesi amacıyla, Nevşehir Rehberler Odasına (NERO) bağlı turist rehberleri üzerinde bir alan araştırması yapılmış ve veriler anket yardımıyla toplanmıştır. Yapılan analizler sonucunda, tükenmişliğin boyutlarından duygusal tükenme ve duyarsızlaşmanın turist rehberlerinin işe yabancılaşma eğilimlerini doğrusal yönde; kişisel başarı hissinin ise ters yönde etkilediği belirlenmiştir. Değişkenlere ilişkin genel ortalamalar göz önüne alındığında ise, turist rehberlerinin duygusal tükenme ve duyarsızlaşma düzeylerinin düşük olmasının ve kişisel başarı hislerinin yüksek olmasının, işe yabancılaşma eğilimlerini azalttığı sonucu ortaya çıkmaktadır.

Anahtar Kelimeler: Turist Rehberleri, Tükenmişlik, İşe yabancılaşma.

\section{Abstract}

The purpose of this study is to analyze and evaluate the burnout levels of tourist guides regarding to their work alienation tendencies. In order to test the three hypotheses of the study which were developed according to the theoretical frame of burnout and work alienation interaction, a field study was conducted on tourist guides who are registered at Nevşehir Chamber of Guides (NERO) and data were collected through a questionnaire. The results of the analysis show that emotional exhaustion and depersonalization, which are dimensions of burnout, effect work alienation tendency of tourist guides linearly and personal accomplishment effect adversely. Given the overall averages related to variables it is unveiled that the low levels of emotional exhaustion and depersonalization and the high levels of personal accomplishment decrease the work alienation tendencies.

Key Words: Tourist Guides, Burnout, Work alienation 


\section{Giriş}

Her geçen gün değişen ve gelişen insan yaşamı, kişilerin çalışma hayatına önem vermeye başlamasıyla daha farklı bir boyut kazanmıştır. Yoğun ve yorucu bir hayat temposuyla karşı karşıya kalan bireyler iş yaşamı ve sosyal yaşam arasındaki dengeyi sağlamada güçlük çekmeye başlamışlardır. Çalışan bireyler gün içinde çeşitli zorluklarla karşı karşıya kalmakta ve bu zorluklarla baş edemedikleri zaman da tükenmişlik duygusu içine girmektedirler (Durmaz, 2015: 28).

Çalışma ortamında yaşanan sorunlar, ekonomik zorluklar ve diğer sorunlar eklendiğinde, çalışanlar kendilerini tükenmişlik sendromu içinde bulabilmekte, bu durum da kendilerini bulundukları ortamdan giderek soyutlamalarına, işten ve bulundukları ortamdan yabancılaşmalarına neden olmaktadır. Bu sürecin sonunda ise kişi kendisine ve işine yabancılaşmaktadır (Behar, 2007: 109).

Tükenmişlik sendromu yaşayan kişiler iş hayatında, işe devamsızlık, düşük performans, işten ayrılma niyeti gibi olumsuz sonuçlarla karşı karşıya kalabilirler. Bu durum tükenmişlik sendromu yaşayan kişilerde işe yabancılaşma eğiliminin artabileceğini göstermektedir. Bu doğrultuda ele alınan araştırmanın amacı turist rehberlerinin tükenmişlik düzeylerinin işe yabancılaşma eğilimlerine olan etkisini ortaya çıkartmaktır.

Ulusal ve uluslararası yazına bakıldığında tükenmişlik ile işe yabancılaşma konularının bir arada çok az çalışıldığı görülmektedir. Özellikle turist rehberliği alanında bu konuların çalışılmaması bir eksikliği ortaya koymaktadır. Çünkü turist rehberlerinin turizm sektörü açısından önemi büyüktür. Bir turist rehberi ülke turizminin aynası konumundadır. Araştırmacılar da, turizmin gelişmesinde ve turistlerin satın aldıkları turların turistik deneyime dönüşmesinde, rehberlik hizmetinin ve turist rehberlerinin anahtar unsur olduğunu belirtmektedir. Turist rehberlerinin davranışları, toplum ve ülke hakkında fikir ve bilgi vermektedir. Turizm sektörünün başarısı büyük oranda turist rehberlerinin performansına bağlıdır. Bu açıdan bakıldığında turist rehberlerinin tur esnasında sergilemiş oldukları performansları, verimlilikleri, motivasyonları ve buna bağlı olarak iş doyumları, işe bağlııkları yapılan işin kalitesini ortaya koymaktadır.

\section{Literatür Taraması}

\subsection{Yabancılaşma Kavramı}

Yabancılaşma, özellikle günümüz sanayi toplumlarının tüm kurumlarını ve insan ilişkilerini etkileyen bir kavram durumuna gelmiştir (Çağlar, 2012: 197). En yaygın tanımıyla işe yabancılaşma; işin; özerklik, sorumluluk, toplumsal etkileşim ve kendini gerçekleştirme gibi bireyin insan olarak değerini ortaya koyan koşulların ve ortamların sağlanamamasıdır (Mottaz, 1981: 517). İlgili yazında ise yabancılaşma kavramını ele alınırken, çalışmaya karşı alaka göstermemek (Hirschfeld ve Field, 2000: 790), iş üzerinde algılanandan daha az özgürlük ve kontrol sahibi olmak (Patrick, 1984; Pearlin, 1962), kariyer hedeflerinden uzaklaşma ve profesyonel normlara uyum sağlayamamadan oluşan olumsuz duygular (Aiken ve Hage, 1966: 497) şeklinde tanımlamalar kullanıımıştır.

Yönetim yazınında yabancılaşma üzerine süregelen teorik ve ampirik çalışmalar, şimdiye kadar yabancılaşmaya etki eden birçok faktör üzerinde durmuştur. Bireyin işine yönelik yabancılaşma eğilimine etki eden unsurları Seeman (1959) güçsüzlük, 
anlamsızlık, kuralsızlık, yalıtılmışlık ve kendine yabancılaşma şeklinde boyutlandırmıştır.

Seeman'a göre; güçsüzlük durumu, klasik literatür açısından, kişinin mevcut olaylar üzerindeki gücünü, etkisini, kontrolünü ve özerkliğini yitirmesi olarak tanımlanmaktadır (Seeman, 1983: 173; Babür, 2009: 25). Anlamsızlık, bireyin karar vermek zorunda olduğu anda, kararını verirken neye inanacağını bilememesi ve kafa karışıklığı yaşaması durumudur (Tekin, 2012). Normsuzluk, kurallara olan bağııı̆ı̆n azalması sonucu bireylerin düzensizlik, kargaşa, kararsızlık, karamsarlık ve belirsizlik duyguları içine düşmelerini ifade eden bir kavramdır (Dean, 1961: 754-755). Topluma yabancılaşma ise, toplum tarafından yüksek değer verilen amaçlar ve inançların birey için bir anlam ifade etmemesi olarak tanımlamaktadır (Seeman, 1959). Kendine Yabancılaşma ise, kişinin belirli bir davranışının, geleceğe yönelik beklentileri ile uyuşmaması, beklentilerinin dışına çıkarak farklı davranması durumudur. (Seeman, 1983; Yumuk, 2011: 23).

\subsection{Tükenmişliğin Kavramsal Analizi ve Boyutları}

Çalışanlarda işe yabancılaşmaya neden olan tüm bu unsurlar genel olarak ele alındığında, tüm bu olumsuz duygu ve davranışların bireydeki tükenmişliğin bir sonucu olarak gelişebilme intimali göz ününe gelmektedir. Tükenmişlik, bireyin fiziksel yorgunluk, çaresizlik ve ümitsizlik duygusu, duygusal boşluk, olumsuz öz-algının gelişmesi ve işe, yaşama ve diğer insanlara olumsuz tutumların gelişmesidir (Gold, 2001: 254). Kişinin iç kaynakları üzerinde karşılanamayan istek ve taleplerden ötürü ortaya çıkan tükenme durumu, "başarısızlık, yıpranma, enerji ve güç kaybı" kelimeleriyle ifade edilmiştir (Sowmya ve Panchanatham, 2011: 51).

İnsana hizmet veren, eğitim ve sağlık gibi insan odaklı mesleklerde sıklıkla görülen tükenmişlik olgusunu Christina Maslach "profesyonel bir kişinin mesleğinin özgün anlamı ve amacından kopması, hizmet verdiği insanlar ile gerçekten ilgilenemiyor olması" biçiminde tanımlamıştır (Leiter ve Maslach, 2001: 415-416). Ayrıca Maslach, tükenmişliği "işi gereği insanlarla yoğun ilişki içerisinde olanlarda görülen, duygusal tükenme, duyarsızlaşma ve düşük kişisel başarı sendromu" şeklinde tanımlamıştır (Brouwers ve Tomic, 2000: 239; Maslach ve diğ., 2001: 206; Toprak, 2013: 11).

Tükenmişliğe neden olan boyutları ortaya koymak amacıyla geliştirilen Maslach tükenmişlik modeli, literatürde "çok boyutlu tükenmişlik modeli" ya da "üç boyutlu tükenmişlik modeli” olarak tanımlanmaktadır (Gül, 2014: 13; Kulaklıkaya, 2013: 29). Bu üç boyutlu tükenmişlik kavramının merkezinde "duygusal tükenme" boyutunun yer aldığı, diğer iki boyutun ise (duyarsızlaşma ve kişisel başarı hissi) bunu tamamlayan boyutlar olduğu ileri sürülmektedir (Bkz: Şekil 1) (Alkan, 2014: 6).

Şekil 1: Maslach Tükenmişlik Modeli

$$
+ \text { Duygusal Tükenme } \longrightarrow+\text { Duyarsızlaşma } \longrightarrow \text { - Kişisel Başarı }
$$

Maslach'a göre tükenmişliğin en önemli bileşeni duygusal tükenmişliktir (Gaines ve Jermier, 1983). Tükenmişlik sendromunun başlangıcı ve merkezi olan duygusal tükenmişlik, genel bir duygu, ilgi ve güven kaybı yanında yorgunluk, kullanılmışlık, sinirlilik, hayal kırıklığı ve yıpratılmışlık duygularını da içerir (Cordes ve diğ., 1997). Çalışanların örgütsel ve kişisel yöndeki beklentilerinin duygusal tükenmişlikle doğrudan 
ilişkili olduğu bilinmektedir. Araştırmalar yoğun ilişkilerin uzun süre devam ettirilmesinin gerekli olduğu işlerde çalışanlarda gözlenen duygusal tükenmişliğin, rutin işlerde çalışanlarda gözlenen duygusal tükenmişlikten daha fazla olduğunu belirtmektedir (Tuğrul ve Çelik, 2002: 1).

Duygusal anlamda tükenen birey bir sonraki aşamada çevresindeki insanlarla olan ilişkisini sınırlandırarak psikolojik olarak insanlardan uzaklaşır. Bu şekilde duyarsızlaşma boyutu kendisini gösterir (Ardıç ve Polatçı, 2008: 71). Maslach'a göre tükenmişliğin üç bileşeninden duyarsızlaşma alt boyutu en problemli boyut olarak görülmektedir (Çelikkaleli, 2011). Duyarsızlaşma, tükenmişliğin kişiler arası boyutunu temsil etmekte ve müşterilere yönelik olumsuz, katı tutumları ve işe karşı tepkisizleşmeyi belirtmektedir (Budak ve Sürgevil, 2005: 96). Duyarsızlaşma yaşayan bireyler, kendisini diğer insanların sorunlarını çözmede güçsüz hissetmekte ve duyarsızlaşmayı bir kaçış yolu olarak kullanmaktadır. İşin yapılabilmesi için gerekli olan insanlarla ilişkilerini en alt seviyeye indirmekte ve hizmet verdikleri kişilere karşı uzaklaşmaktadır (Şıklar ve Tunalı, 2012: 76).

Maslach ve Jackson (1986)'a göre kişisel başarı sürecinde bireyde oluşacak olumsuz yargılar, onun mesleğine yönelik işlevsellik düzeyinde düşüşü meydana getirecektir. "Depresyon, düşük moral, insanlardan uzaklaşma, azalan verimlilik, baskıyla başa çıkamama, başarısızlık hissi ve kendine güvenin zayıflığı kişisel başarısızlığın özelliklerindendir" (Hock, 1988). "İnsanlar, çabalarının olumlu sonuçlar üretmede sürekli başarısız hale geldiği durumlarda, stres ve depresyon belirtisi geliştirirler; davranışlarının bir fark yaratmadığına inandıklarında çabalamayı bırakırlar" (Jackson ve diğ., 1986). Sonuç olarak birey işinde ya da etkileşim içinde bulunduğu insanlarla ilişkilerinde genel bir yetersizlik ve başarısızlık hissetmeye başlamaktadır (Sağlam Arı ve Çına Bal, 2008: 134).

\subsection{Tükenmişliğin İşe Yabancılaşmaya Etkisi}

Tükenmişlik, üç boyutlu bir sendrom olup, yabancılaşma kavramı tükenmişliğin bu alt boyutları içerisinde vurgulanmaktadır. Duygusal tükenme sonucunda kişi işe olan bağlıığını kaybetmekte ve böylelikle işe devamsızlıktan işten ayrılmaya kadar giden davranışlar göstermektedir. Bu durum yabancılaşmanın bir sonucu olarak görülmektedir. Duyarsızlaşma boyutunun altında bir yabancılaşma duygusu ve savunma mekanizması yatmaktadır. Kişi çevresinde bulunan insanları iş nesnesi olarak görmeye başladığı anda kendi içinde ki insana ve çevresine yabancılaşmaya başlamaktadır. Kişisel başarıda düşme gerçekleştiğinde ise işle ilgili çeşitli olaylarda kendini yetersiz algılama ve işyerinde karşılaşılan kişilerle olan ilişkilerde de başarısızlık duygusu baş gösterir. Böylece harcadığı çabanın boşa gitmesi ve suçluluk duygusu çalışanın iş motivasyonunu düşürerek başarı için gerekli davranışları gerçekleştirmesini engeller ve işe yabancılaşma başlar (Celep, 2008: 77).

Yabancılaşmada olduğu gibi tükenmişlik sendromu da bir süreci ifade etmektedir. Tükenmişlik sendromu beklentilerin fazla, beklentileri karşılayabilmek için fiziksel ve duygusal imkanların az olması durumunda ortaya çıkmaktadır. Çalışanın, işinde kontrolünün olmadığını hissetmesi, yaşamış olduğu olaylarda hiçbir şey yapamadığını düşünmesi ve herhangi bir biçimde söz sahibi olmadığını anlaması kendini zayıf hissetmesine sebep olacaktır. İnsanın güçsüzlük durumunu aralıksız yaşaması, tükenmişlik duygusunun gelişmesine neden olacaktır. Güçsüzlük tükenmişliğin psikolojik belirtilerinden biri olmakla birlikte yabancılaşmanın da bir alt boyutu olarak karşımıza çıkmaktadır. Güçsüzlük boyutu, Seeman'ın boyutlandırması içerisinde birçok farklı bilim dalından araştırmacı tarafından üzerinde en fazla 
yoğunlaşılan boyut olmuştur. Seeman'a göre; güçsüzlük durumu, klasik literatür açısından, kişinin mevcut olaylar üzerindeki gücünü, etkisini, kontrolünü yitirmesi olarak tanımlanmaktadır. Bu algıya sahip bireyler yaptıkları iş üzerinde egemenlik duygusunu yaşayamadıkları için geleceği kontrol edememe kaygısını da içlerinde taşır hale gelirler. Böylelikle bireyler yaptıkları işe karşı yabancılaşma eğilimi göstereceklerdir (Ergun Özler ve Dirican, 2014).

İşe yabancılaşma ile tükenmişlik arasındaki etkileşimi ele alan öncül çalışmalar iki kavram arasındaki etkileşimin teorik temellerini ortaya koymaktadır. Igodan ve Newscomb (1986) tükenmişliğin fiziksel, psikolojik ve davranışsal sonuçlarını tartışırken, özellikle psikolojik ve davranışsal sonuçlarla yabancılaşma arasında bazı ilişkiler kurmuştur. Örneğin güçsüzlük ve değersizlik duygusu, karamsarlık, özbenliğini yitirme, ideallerinden uzaklaşma, suçluluk-başarısızlık, iş ile ilgili şikâyetlerde artış, işe yoğunlaşamama, çalışma coşkusunu kaybetme, iş ya da iş yeri değişikliğinde artış, iletişimi azaltma, çekilme ve kendini soyutlama gibi işe yabancılaşmanın sonuçlarıyla örtüşen temel bazı benzerlikler göstermiştir. Hatta Igodan ve Newscomb (1986) daha da ileri giderek yabancılaşmayı tükenmişliğin psikolojik bir göstergesi olarak değerlendirmiştir. Benzer biçimde Rabinowitz (1985) çalışma özerkliği, tükenmişlik ve işe yabancılaşma ile ilgili yaptığı araştırmada yabancılaşmanın tükenmişliğin psikolojik bir belirtisi olduğu bulgusunu destekleyici sonuçlara varmıştır.

2000'li yıllara gelindiğinde ise tükenmişlik ile yabancılaşma arasındaki etkileşim daha detaylı incelenmiş ve elde edilen istatistiksel bulgular neticesinde iki kavram arasındaki ilişki nitel ve nicel verilerle desteklenmiştir. Tomei ve çalışma arkadaşları (2011), tükenmişlik ve yabancılaşmayı, her zaman birbiriyle doğrusal bir biçimde etkileşim halinde olan iki kavram olarak göstermiştir. Carton (2016) ise benzer biçimde, tükenmişlik sorununun, yabancılaşma olgusuna geçişte bir referans olduğunu ileri sürmektedir.

Chiaburu, Thundiyil ve Wang (2014), yaptıkları meta-analiz sonucu tükenmişliği yabancılaşmanın, çalışan sağlığı ile ilgili sorun yaratan çıktılardan biri olarak göstermiştir. O'Donohue ve Nelson (2012) ise, örgütsel psikoloji alanında yapmış oldukları çalışmalar neticesinde, yabancılaşma, işle bağlarını koparma ve tükenmişlik arasında karşılıklı olarak güçlü bir etkileşimin varlığına ve bu üç kavramın bir arada iş memnuniyetini ve performansını düşürdüğüne işaret etmektedir. Osin (2003), tükenmişlik ile yabancılaşmanın hayatın her alanında birbiri ile ilişkili kavramlar olduğunun altını çizmektedir. 2015 yılında üniversite öğrencilerini konu alan çalışmasında Osin (2015), öğrencilerin tükenmişlik düzeylerinin, çalışmaya karşı yabancılaşma hissi doğurduğunu belirlemiştir. Yine Taboli (2015) üniversite çalışanları üzerinde yaptığı çalışma neticesinde, işe yabancılaşma ile tükenmişlik arasında \%25 oranında pozitif anlamlı bir etkileşim belirlemiş ve bu iki kavramın çalışanların işten ayrılma niyetlerini etkilediğini tespit etmiştir.

İki kavram arasındaki etkileşime yönelik Türkiye'de yapılan çalışmalar incelendiğinde ise uluslararası yazını destekler nitelikte sonuçlara ulaşıldığı görülmektedir. Bu kapsamda, Behar (2007), endüstri sektöründe gerçekleştirdiği çalışma sonucunda yabancılaşma ile tükenmişlik arasında doğrusal yönlü ve güçlü bir ilişki bulmuştur. Usul ve Atan (2014), sağlık sektöründe yaptıkları çalışmada tükenmişliği yabancılaşmanın göstergelerinden biri olarak tespit etmiştir. Tükenmişlik ile yabancılaşma arasında ortaya konulan etkileşim düzeyi, bu konuda yapılan diğer çalışmalarda da benzer sonuçlar vermiştir (Çetin, 2013; Ergun Özler ve Dirican, 2014). 


\section{Araştırmanın Yöntemi}

\subsection{Araştırmanın Hipotezleri}

Literatür taraması sonucu elde edilen güçlü teorik bulgulardan yola çıkarak bu araştırma dahilinde üç hipotez geliştirilmiş ve uygun istatistiki yöntemlerle analiz edilmesi amaçlanmıştır. Geliştirilen üç araştırma hipotezi şunlardır:

$\mathbf{H}_{1}$ : Duygusal tükenme turist rehberlerinin işe yabancılaşma eğilimlerini doğrusal yönde etkiler.

$\mathbf{H}_{2}$ : Duyarsızlaşma turist rehberlerinin işe yabancılaşma eğilimlerini doğrusal yönde etkiler.

$\mathbf{H}_{3}$ : Kişisel başarı hissi turist rehberlerinin işe yabancılaşma eğilimlerini ters yönde etkiler.

Turist rehberlerinin yabancılaşma düzeylerine etki eden tükenmişlik boyutlarının belirlenmesi amacıyla oluşturulan araştırma hipotezlerinin test edilmesinde anket tekniğinden yararlanılmıştır. Oluşturulan anket formu Nevşehir ilinde aktif olarak faaliyet gösteren rehberler üzerinde uygulanmıştır.

\subsection{Veri Toplama Aracı ve Güvenilirlik Analizleri}

Oluşturulan anket formu üç bölümden oluşmaktadır. İlk bölümde araştırmaya katılan turist rehberlerine ilişkin demografik ve kişisel bilgilerin belirlenmesi amacıyla anket formuna altı kapalı uçlu soru yöneltilmiştir. İkinci bölümde tükenmişlik, üçüncü bölümde ise yabancılaşma ölçeği anket formuna dahil edilmiştir.

Tükenmişliği oluşturan her bir boyuta ilişkin ölçek oluştururken, literatür taraması sonucunda 1981 yılında Christina Maslach ve Susan Jackson tarafından hazırlanan "Maslach Tükenmişlik Ölçeği" kullanılmıştır. Orijinal ölçek 22 sorudan oluşmaktadır. Bu ifadelerin 9'u "duygusal tükenme", 5'i "duyarsızlaşma" ve 8'i "kişisel başarı hissi" boyutlarını ölçmeye yönelik olarak oluşturulmuştur. Ölçeğin Türkçe uyarlaması ve geçerlilik-güvenilirlik çalışması Ergin (1992) tarafından yapılmıştır. Ergin (1992) tarafından yapılan analizler sonucunda, ölçeğin iç tutarlılığı için Cronbach Alfa değerleri sırasıyla $0,83,0,71$ ve 0,72 olarak elde edilmiştir.

İşe yabancılaşmanın ölçülmesinde Hirschfeld ve Field (2000) tarafından geliştirilen ve Türkçe uyarlaması Özbek (2011) tarafından yapılan ölçek kullanılmıştır (Örnek ifade: İşten keyif alamıyorum, onu sadece verdiğim zaman karşılığında aldığım para olarak görüyorum). Ölçeğin, Özbek (2011)'in çalışmasında tek faktörlü yapısının bulunduğu ifade edilmiştir. Tükenmişlik ve işe yabancılaşma ölçeği beş boyuttan oluşan Likert-5'li bir ölçektir. Ölçekte yer alan ifadeler "Hiç katılmıyorum" (1), "Az katılıyorum" (2), "Orta derecede katılıyorum" (3), "Katılıyorum" (4) ve "Tamamen katılıyorum" (5) değerine karşılık gelmektedir.

Araştırma dâhilinde oluşturulan tükenmişlik ve işe yabancılaşma düzeyi ölçeklerine yönelik güvenilirlik analizi yapılmıştır. Buna göre, duygusal tükenmenin güvenilirlik katsayısı, Alpha $(\alpha)=0,87$; duyarsızlaşmanın güvenilirlik katsayısı, Alpha $(\alpha)=0,72$; kişisel başarı hissinin güvenilirlik katsayısı, Alpha $(\alpha)=0,70$; işe yabancılaşma ölçeğinin güvenilirlik katsayısı, Alpha $(\alpha)=0,86$ olarak belirlenmiştir. Bu sonuçlara göre, araştırmada veri toplama aracı olarak kullanılan anketin güvenilirlik düzeyinin yüksek olduğu söylenebilir. 


\subsection{Araştırmanın Evreni ve Örneklem Büyüklüğü}

Araştırmanın evrenini Nevşehir Rehberler Odası (NERO)'na bağlı profesyonel turist rehberleri oluşturmaktadır. Bu bağlamda 2015 yılı verilerine göre NERO'ya bağlı toplam 554 profesyonel turist rehberi bulunmaktadır. Turist rehberlerinden 476 kişi eylemli, 79 kişi ise eylemsiz rehber olarak görülmektedir. 476 kişiden oluşan evren içinde minimum örneklem sayısı 213 olarak görülmektedir (Altunışık ve diğ., 2012). Bu araştırma kapsamında 220 rehberden sağlıklı bir geri bildirim alınmıştır.

Araştırma verileri 2015 yılı Aralık ve 2016 yılı Ocak aylarında toplanmıştır. Anket formalarının doldurulmasında ise, birebir görüşme yoluyla veya Nevşehir Rehberler Odası (NERO) kanalıyla turist rehberleri ile iletişime geçilmiş ve geribildirim alınmıştır.

Yapılan anket çalışması sonucunda elde edilen veriler, "IBM SPSS Statistics 21.0" programı kullanılarak, uygun istatistiki yöntemler aracılığıyla test edilmiş ve söz konusu verilerin dokümantasyonu yine uygun yöntemlerle yapılmıştır. Araştırmaya katılan profesyonel turist rehberlerinin cinsiyete göre dağılımı incelendiğinde toplam 220 profesyonel turist rehberinin 123'ünün (\% 55,9) erkek, 97'sinin (\% 44,1) kadın olduğu görülmektedir. Profesyonel turist rehberlerinin yaşa göre dağılımına bakıldığında büyük bir kısmını 21-30 yaş arası ( $n=114 ; \% 51,8)$ genç rehberler oluşturmaktadır. Katılımcıların eğitim düzeylerine ilişkin sonuçlar incelendiğinde ise, büyük bir kısmını lisans eğitimi ( $n=161$; \% 73,2) almış rehberlerin oluşturduğu görülmektedir. Son yasaya göre turist rehberliğinin ön şartlarından biri önlisans veya lisans mezunu olmaktır. Bu nedenle profesyonel turist rehberlerinin eğitim durumu araştırma sonuçlarına göre oldukça yüksek görülmektedir. Katılımcıların eğitim düzeyine ilişkin faktörlerin incelenmesinde, turizm eğitimi göz ardı edilmemiştir. Araştırma sonuçlarına göre katıımcıların \% 80,9'u $(n=178)$ turizm eğitimi almışken, $\% 19,1^{\prime} i(n=42)$ turizm sektörüne dönük herhangi bir eğitim almamıştır.

Araştırmaya katılan profesyonel turist rehberlerinin sektördeki çalışma süresine bakıldığında, \% 39,1'inin ( $n=86$ ) 1-5 yıl; \% 25,9'unun $(n=57) 6-10$ yıl; \% 17,3'ünün ( $n=$ 38) 11-15 yıl; \% 9,1'inin ( $n=20)$ 16-20 yıl; \% 4,5'inin $(n=10) 21$ yıl ve üzeri; \% 4,1'in $(n=9)$ ise 1 yıldan az süredir sektörde çalıştığı görülmektedir.

\section{Araştırma Bulguları}

\subsection{Değişkenlere İlişkin Genel Ortalamalar ve Korelasyon Analizi Bulguları}

Profesyonel turist rehberlerinin tükenmişlik düzeyleri ile işe yabancılaşma eğilimlerine ilişkin genel ortalamalara ve iki değişken arasındaki ilişkinin şiddetini ve yönünü ortaya koyan korelasyon analizi sonuçlarına Tablo 1'de yer verilmektedir.

Tablo 1: Aritmetik Ortalamalar, Standart Sapmalar ve Korelasyon Katsayıları

\begin{tabular}{|l|c|c|c|c|c|c|}
\hline \multicolumn{1}{|c|}{ Değişkenler } & A.0. & $\begin{array}{c}\text { Std. } \\
\text { Sapma }\end{array}$ & $\mathbf{1}$ & $\mathbf{2}$ & $\mathbf{3}$ & $\mathbf{4}$ \\
\hline Duygusal Tükenme (1) & 2,18 & 0,79 & 1 & & & \\
\hline Duyarsızlaşma (2) & 1,78 & 0,74 &, $683^{\star *}$ & 1 & & \\
\hline Kişisel Başarı (3) & 4,06 & 0,59 &,$- 363^{* *}$ &,$- 365^{\star *}$ & 1 & \\
\hline IŞe Yabancılaşma (4) & 2,06 & 0,73 &, $588^{* *}$ &, $519^{* *}$ &,$- 340^{* *}$ & 1 \\
\hline
\end{tabular}

Tükenmişliğin duygusal tükenme boyutuna ilişkin, profesyonel turist rehberlerinin vermiş oldukları yanıtlara bakıldığında düşük ortalamalar ile karşılaşılmaktadır (Genel 
ortalama $=2,18$; standart sapma $=0,79) . B u$ nedenle turist rehberlerinin büyük bir çoğunluğunun bu işi yapmaktan memnun olduklarını söylemek mümkündür. Duyarsızlaşma boyutuna ilişkin, ankete verilen cevaplar incelendiğinde ise, benzer biçimde duygusal tükenme gibi düşük değerler ile karşılaşılmıştır (genel ortalama= 1,78; standart sapma $=0,74)$. Bu sonuçlara göre profesyonel turist rehberlerinin işleri gereği karşılaştıkları insanlara karşı oldukça duyarlı oldukları söylenebilir. Tükenmişliğin son boyutu olan kişisel başarı hissinde ise oldukça yüksek değerler ile karşılaşılmıştır (genel ortalama= 4,06; standart sapma= 0,59). Profesyonel turist rehberlerinin işlerine karşı kişisel başarı hissi duydukları görülmektedir. İşe yabancılaşmaya ilişkin ifadelerin ortalamalarına bakıldığında, profesyonel turist rehberlerinde işe yabancılaşma eğilimlerinin düşük değerlerde olduğu görülmektedir (genel ortalama $=2,06$; standart sapma $=0,73$ ).

Yapılan korelasyon analizinde, tükenmişliği oluşturan boyutlardan duygusal tükenme, duyarsızlaşma ve kişisel başarı ile yabancılaşma arasında güçlü denebilecek anlamlı bir ilişki olduğu saptanmıştır. Duygusal tükenme ile işe yabancılaşma arasındaki ilişkinin yönü doğrusaldır $(r=0,588, p=, 000<0,05)$. Sonuçta, turist rehberlerinde duygusal tükenme azaldıkça, işe yabancılaşma eğilimi de azalmaktadır. Benzer biçimde duyarsızlaşma ile işe yabancılaşma arasında da orta düzeyde doğrusal bir ilişki saptanmıştır $(r=0,519, p=, 000<0,05)$. Profesyonel turist rehberlerinin duyarsızlaşma düzeyleri azaldıkça, işe yabancılaşma eğilimleri de azalmaktadır. Son olarak kişisel başarı hissi ile işe yabancılaşma arasındaki ilişkinin yönü ise ters yönlüdür $(r=-0,340, p=, 000<0,05)$. Yani profesyonel turist rehberlerinin kişisel başarıları arttıkça, işe yabancılaşma eğilimleri düşmektedir.

\subsection{Regresyon Analizi Sonuçları ve Hipotez Testleri}

Araştırmaya konu olan değişkenler arasındaki etkileşimi belirlemek ve araştırma dahilinde daha önce geliştirilen hipotezleri test etmek amacıyla, bu çalışma kapsamında çoklu regresyon analizi yapılmış ve sonuçlar değerlendirilmiştir (Bkz: Tablo 2).

Tablo 2: Tükenmişlik ile İşe Yabancılaşma Arasındaki İlişkileri İnceleyen Çoklu Regresyon Analizi

\begin{tabular}{|c|c|c|c|}
\hline $\begin{array}{c}\text { BAĞIMSIZ } \\
\text { DEĞiŞKENLER }\end{array}$ & BETA & $\mathbf{T}$ & SIG. $(P)$ \\
\hline Duygusal Tükenme &, $412^{\star *}$ & 5,560 & 000 \\
\hline Duyarsızlaşma & $194^{\star *}$ & 2,610 & ,010 \\
\hline Kişisel Başarı &,$- 120^{*}$ & $-2,066$ & ,040 \\
\hline $\mathbf{F}$ & \multicolumn{3}{|c|}{44,896} \\
\hline $\mathbf{R}$ & \multicolumn{3}{|c|}{,620 } \\
\hline $\mathbf{R}^{2}$ (Adjusted) & \multicolumn{3}{|c|}{$384^{*}$} \\
\hline
\end{tabular}

Tablo 2'de tükenmişlik ile işe yabancılaşma eğilimi arasındaki ilişkileri inceleyen çoklu regresyon analizi sonuçlarına yer verilmiştir. Burada duygusal tükenme, duyarsızlaşma ve kişisel başarı bağımsız değişkenler olup, işe yabancılaşma eğilimi ise bağımlı değişkendir.

Model işe yabancılaşma değişiminin \% 38,4 $\left(\mathrm{R}^{2}\right)$ 'ünü açıklamaktadır. Diğer bir deyişle, tükenmişliği oluşturan boyutlar (duygusal tükenme, duyarsızlaşma ve kişisel başarı), işe yabancılaşma eğilimindeki değişimin \% 38,4'ünü açıklamaktadır. Tablo 2'ye göre, duygusal tükenme ve duyarsızlaşmanın işe yabancılaşma eğilimine olan 
etkisinin doğrusal yönlü olduğu, kişisel başarının işe yabancılaşma eğilimine olan etkisinin ise ters yönlü olduğu sonucu ortaya çıkmaktadır. Duygusal tükenme bir birim arttığında işe yabancılaşma 0,412 (Beta1), duyarsızlaşma bir birim arttığında ise işe yabancılaşma 0,194 (Beta2) artmaktadır. Bunun aksine kişisel başarı bir birim arttığında işe yabancılaşmanın 0,12 (Beta3) kadar azalacağını söylemek mümkündür. $\mathrm{O}$ halde $\mathrm{H} 1, \mathrm{H} 2$ ve $\mathrm{H} 3$ hipotezlerini test etmek amacıyla oluşturulan regresyon modeli geliştirilen araştırma hipotezlerinin tamamını destekler niteliktedir.

\section{Sonuç ve Tartışma}

Tükenmişliğin insanların işleri nedeniyle kurdukları ilişkiler ve ilişkilerin kötüye gitmesi sonucunda ortaya çıkan zorluklarla ilgili sosyal bir problem olması, tükenmişliği emeğin yoğun olduğu meslek gruplarında görülen mesleki bir hastalık haline getirmiştir. Yabancılaşma kavramı da benzer biçimde, günümüz meslek gruplarında sıklıkla karşılaşılan psikolojik ve sosyolojik bir sorun kaynağıdır.

$\mathrm{Bu}$ çalışma sonucu elde edilen nicel veriler ışığında, profesyonel turist rehberlerinin tükenmişlik düzeylerinin işe yabancılaşma eğilimlerini etkilediğine yönelik güçlü istatistiksel bulgulara ulaşılmıştır.

Ülke turizminin daha iyi noktalara ulaşmasında turist rehberleri önemli bir paya sahiptir. Günümüzde de turist rehberleri, turizm sektörünün vazgeçilmez dinamiklerinden biri haline gelmiştir. Özellikle kitle turizminin artış gösterdiği son yıllarda seyahat amacı ne olursa olsun seyahat acentelerine olan talep artmakta ve buna bağlı olarak turist rehberlerine olan talep de artmaktadır. Bununla birlikte turist rehberi ülke turizminin aynası konumundadır. Ülkeyi ve halkı yabancılara karşı kendi kimliği ile temsil etmek en büyük sorumluluklardan biridir. Turist rehberlerinin yaptıkları işin kalitesinin işe olan bağlılıklarına ve performanslarına bağlı olduğunu söylemek mümkündür. Yapılan araştırmada da turist rehberlerinin tükenmişlik düzeyleri ve işe yabancılaşma eğilimleri oldukça düşük çıkmıştır. Bu durum göstermektedir ki turist rehberleri yaptıkları işi yüksek düzeyde bir doyum ve motivasyon ile yapmaktadırlar.

Tükenmişlik ile işe yabancılaşma kavramları arasındaki etkileşim turist rehberleri açısından, kurumsal bir örgüte nazaran birtakım farklılıklar içermektedir. Örneğin, örgütler insan faktörünün bir arada kurumsal bir eşgüdüm halinde çalıştığı yapılarken, turist rehberleri bireysel performansı ile hizmet sunan çalışanlardır. Müşteri memnuniyetini bireysel yetenekleri ile tek başına üstlenen turist rehberlerinin genel olarak iş üzerindeki kontrolü ve özerkliği yüksektir. Mesleki başarısı bireysel performansına bağlı olan rehberlerin aynı zamanda, hizmet ettiği müşterilerine karşı da sosyo-kültürel temellere dayalı güçlü bir iletişim kurması önemlidir. Bu nedenle güçsüzlük, kuralsızlık, anlamsızlaşma ve topluma yabancılaşma gibi faktörler tarafından beslenen işe yabancılaşmanın rehberler üzerinde düşük düzeyde sonuçlar vermesi, rehberlerin mesleki gelişimi ve devamlılığı açısından önemli bir sonuçtur. Ancak bununla birlikte, hizmet sunduğu müşterileri ile sürekli ve etkili bir iletişim kurması gerekliliği ve müşteri memnuniyeti açısından bütün sorumluluğu tek başına üstleniyor olmaları, turist rehberlerinin mesleğinde çabuk tükenme eğilimi göstermelerine neden olabilir. Bu çalışmaya katılan turist rehberlerinde bu tür olumsuz bir eğilim belirlenmemiştir. Elde edilen istatistiki bulgular göstermektedir ki, tükenmişlik düzeylerinin düşük olması aynı zamanda işe yabancılaşma eğilimlerinin de düşük düzeyde olması sonucunu beraberinde getirmiştir. Araştırma kapsamında yapılan korelasyon analizi sonuçlarına bakıldığında, tükenmişliği oluşturan boyutlardan 
duygusal tükenme, duyarsızlaşma ve kişisel başarı ile yabancılaşma arasında güçlü denebilecek anlamlı bir ilişki olduğu saptanmıştır.

Turist rehberlerinin işe yabancılaşma eğilimlerinin açıklanmasında sadece işe yabancılaşmayı meydana getiren unsurların değil aynı zamanda tükenmişlik düzeylerinin de etkili bir unsur olduğu bu çalışma ile geliştirilen üç araştırma hipotezinin kabul görmesi ile saptanmıştır.

Geliştirilen ilk araştırma hipotezi duygusal tükenmenin, ikinci hipotez duyarsızlaşmanın ve üçüncü hipotez ise kişisel başarı hissinin işe yabancılaşma üzerindeki etkisini test etmeyi amaçlamıştır. Yapılan çoklu regresyon analizi sonucunda elde edilen verilere bakıldığında bu hipotezlerin tamamının desteklendiği görülmektedir. Dolayısıyla, düşük düzeyde duygusal tükenme ve duyarsızlaşma ile yüksek düzeyde kişisel başarı hissi turist rehberlerinin işe yabancılaşma eğilimlerini azaltmaktadır. Rehberlerin işe yabancılaşma eğilimlerinin azalmasında en çok duygusal tükenmişlik düzeyinin etkisinin olduğu göze çarpmaktadır. Bu sonuca göre, duygularının kontrolünü elinde tutan ve mesleği ile olumlu duygusal bağ geliştiren rehberlerin, mesleğinde kendisini daha güçlü ve verimli hissettiği söylenebilir.

Tükenmişlik, insanlara doğrudan hizmet verilen mesleklerde ya da işlerde çalışan kişilerin sıklıkla yaşadıkları, fiziksel, duygusal ve zihinsel yorgunluğa yol açan bir sendrom olarak görülmektedir. Bu kategoride yer alan turist rehberleri, işlerinde yoğun duygusal beklentilerle karşılaştığında, bir süre sonra hizmet verdiği kişilere karşı duyarlılığını ve ilgisini yitirebilmekte, kendisine ve hizmet verdiği kişilere karşı olumsuz duygular geliştirebilmektedir. Böylelikle hem işine hem de kendisine karşı yabancılaşmaya başlayabilmektedir. Bu tür olumsuz bir sürecin, araştırmaya dahil olan turist rehberlerinde şimdilik görülmemiş olması ülke turizmi açısından da olumlu bir gelişmedir. Ancak son dönemlerde meydana gelen ulusal çapta terör olayları sonucu turizm sektörünün olası bir kriz ile yüzleşmesi durumunda, rehberlerin de bu kriz sürecinden etkilenebileceği bir gerçektir. Böyle bir süreçte turizm sektöründe görev yapan bireylerin, duygusal ve zihinsel yönden kendilerini koruyabilmeleri, sürekli dinamik kalabilmeleri ve mesleki bağlılıklarını her koşulda sağlayabilmeleri önemlidir.

Her geçen gün insan ilişkilerinin daha da karmaşıklaşması, özellikle yüz yüze ilişkilerin yoğun olduğu meslek gruplarında, turist rehberleri üzerinde ilk kez yapılan bu tür araştırmaların gelecek dönemlerde de tekrarlanmasında fayda vardır. Bu çalışma, farklı sektörlerde farklı sonuçlar verebilir. Bu nedenle ileride yapılacak bilimsel çalışmalar, bu konunun farklı sektörlerde değerlendirilmesi üzerine yoğunlaşabilir. Aynı zamanda bu çalışma farklı bölgelerde yer alan turist rehberleri üzerine de uygulanabilir. Tükenmişlik kavramının, iş tatmini, iş doyumu, mobbing, stres gibi diğer kavramlarla ilişkisi veya etkileşimi yine turist rehberleri üzerine uygulanarak incelenebilir. Ayrıca tükenmişlik ile yabancılaşma arasındaki etkileşimde birtakım aracı değişkenlerin varığı da söz konusu olabilir (işten ayrılma niyeti, iş gerilimi, stres gibi). Bu kapsamda uluslararası yazında ciddi eksiklikler göze çarpmaktadır.

\section{Kaynakça}

Aiken, M. ve Hage, J. (1966), 'Organizational Alienation: A Comparative Analysis' American Sociological Review, 31(4), ss. 497-507.

Alkan, M F. (2014), Ortaokul Öğretmelerinin Tükenmişlik Düzeyi ve Nedenleri, Yayınlanmamış Yüksek Lisans Tezi, İstanbul Aydın Üniversitesi, Sosyal Bilimler Enstitüsü, İstanbul. 
Altunışık, R., Coşkun, R., Bayraktaroğlu, S. ve Yıldırım, E. (2012), Sosyal Bilimlerde Araştırma Yöntemleri SPSS Uygulamalı, Sakarya: Sakarya Yayıncılık.

Ardıç, K. ve Polatçı, S. (2008), 'Tükenmişlik Sendromu Akademisyenler Üzerinde Bir Uygulama (GOÜ Örneği)' Gazi Üniversitesi Iktisadi ve Idari Bilimler Fakültesi Dergisi, 10(2), ss. 69-96.

Babür, S. (2009), Turizm Sektöründe Örgütsel Yabancılaşma: Antalya Beş Yıldızı Konaklama İşletmelerine Yönelik Bir Araştırma, Yayınlanmamış Yüksek Lisans Tezi, Akdeniz Üniversitesi, Sosyal Bilimler Enstitüsü, Antalya.

Behar, R. (2007), Endüstri İşletmelerinde Çalışma Koşullarının, İşgörenler Üzerindeki Yabancılaşma Etkisi ve Bir Uygulama, Yayınlanmamış Yüksek Lisans Tezi, Yıldız Teknik Üniversitesi, Sosyal Bilimler Enstitüsü, İstanbul.

Bostancı, Ö. (2014), Kamu Hastanelerinde Çalışan Diyetisyenlerde Tükenmişlik Düzeyinin Ölçülmesi Üzerine Bir Araştırma; Ankara İli Örneği, Yayınlanmamış Yüksek Lisans Tezi, Türk Hava Kurumu Üniversitesi, Sosyal Bilimler Enstitüsü, Ankara.

Brouwers, A. ve Tomic, W. (2000), 'A Longitudinal Study of Teacher Burnout and Perceived Self-Efficacy in Classroom Management' Teaching and Teacher Education, 16, ss. 239-253.

Budak, G. ve Sürgevil, O. (2005), 'Tükenmişlik ve Tükenmişliği Etkileyen Örgütsel Faktörlerin Analizine İlişkin Akademik Personel Üzerinde Bir Uygulama' Dokuz Eylül Üniversitesi İktisadi ve İari Bilimler Fakültesi Dergisi, 20(2), ss. 95-108.

Carton, T. (2016), 'Burnout as Alienation in the Counselling Field: The Descent from Homo-Faber to Homo-Economous'. Sociology Mind, 6, ss. 33-39.

Celep, B. (2008), İlköğretim Okulu Öğretmenlerinin İşe Yabancılaşması (Kocaeli İli Örneği), Yayınlanmamış Yüksek Lisans Tezi, Kocaeli Üniversitesi, Sosyal Bilimler Enstitüsü, Kocaeli.

Chiaburu, D.S., Thundiyil, T. ve Wang, J. (2014), 'Alienation and İts Correlates: A Meta-Analysis', European Management Journal, 32, ss. 24-36.

Cordes, C L., Dougherty, T W. ve Blum, M. (1997), 'Patterns of Burnout Among Managers And Professionals: A Comparison Of Models', Journal of Organizational Behavior, 18(6), ss. 685-701.

Çağlar, Ç. (2012), 'Öğrenci Yabancılaşma Ölçeğinin (ÖYÖ) Geliştirilmesi' Eğitim ve Bilim, 37(166), ss. 195-205.

Çelikkaleli, Ö. (2011), 'Yetişkin Eğitimcisi Öğretmelerin Tükenmişlik ve Mesleki Yetkinliklerinin İncelenmesi' Mehmet Akif Ersoy Üniversitesi Sosyal Bilimler Enstitüsü Dergisi, 3(4), ss. 38-53.

Çetin, E. ve Turan, N. (2013), 'The Relationship Between Qualitative Job İnsecurity and Burnout', European Journal of Research on Education, Special Issue, ss. 21-28.

Dean, D G. (1961), 'Its Meaning And Measurement' American Sociological Review, 26(5), ss. 753-758.

Durmaz, M. (2015), Sağlık Çalışanlarında Yabancılaşma Düzeyi: Isparta İli Örneği, Yayınlanmamış Yüksek Lisans Tezi, Süleyman Demirel Üniversitesi, Sosyal Bilimleri Enstitüsü, Isparta.

Ergin, C. (1992), 'Doktor ve Hemşirelerde Tükenmişlik ve Maslach Tükenmişlik Ölçeğinin Uyarlanması', Ankara: Türk Psikologlar Derneği Yayınları, , ss. 143154.

Ergun Özler, N D. ve Dirican, M. (2014), 'Örgütlerde Yabancılaşma İle Tükenmişlik Sendromu Arasındaki İlişkiyi Belirlemeye Yönelik Bir Araştırma' Dumlupınar Üniversitesi Sosyal Bilimler Dergisi, 39, ss. 291-310.

Gaines, J. ve Jermier, J M. (1983), 'Emotional Exhaustion in A High Stress Organization' Academy of Management Journal, 26(4), ss. 567-586. 
Gold, Y. (2001), 'Does Teacher Burnout Begin With Student Teaching' Education, 105(3), ss. 254-257.

Gül, B. (2014), Tükenmişlik Ölçekleri ve Erzincan Üniversitesi Örneği, Yayınlanmamış Yüksek Lisans Tezi, Ondokuz Mayıs Üniversitesi, Fen Bilimleri Enstitüsü, Samsun.

Hirschfeld, R R. ve Feild, H S. (2000), 'Work Centrality and Work Alienation: Distinct Aspects of A General Commitment To Work' Journal of Organizational Behavior, 21, ss. 789-800.

Hock, R R. (1988), 'Professional Burnout Among Public School Teachers' Public personnel management, 17(2), ss. 167-189.

Igodan, O C. ve Newcomb, L H. (1986), 'Are You Experiencing Burnout?' Journal of extension, 24(1).

Jackson, S E., Schwab, R L. ve Schuler, R S. (1986), 'Toward An Understanding of The Burnout Phenomenon' Journal of Applied Psychology, 71(4), ss. 630-640.

Kulaklıkaya, K. (2013), İşkoliklik, Tükenmişlik Sendromu ve İ̧̧ Yükü Algısı Arasındaki İlişki, Yayınlanmamış Yüksek Lisans Tezi, Marmara Üniversitesi, Sosyal Bilimler Enstitüsü, İstanbul.

Leiter, M P. ve Maslach, C. (2001), 'Burnout And Health' Handbook of health psychology.

Maslach, C., Schaufeli, W B. ve Leiter, M P. (2001), 'Job Burnout' Annu. Rev. Psychol., 52, ss. 397-422.

Mottaz, C J. (1981), 'Some Determinents of Work Alienation' The Sociological Quarterly, 22(4), ss. 515-529.

O'Donohue, W. ve Nelson, L. (2012), 'Work Engagement, Burn-Out, and Alienation: Linking New and Old Concepts of Positive and Negative Work Experiences', 2012 BAM Annual Conference, Australia.

Osin, E. N. (2003), 'Subjective Experience of Alienation: Measurement and Correlates', https://www.hse.ru/pubs/share/direct/document/76388542 (Erişim Tarihi: 28.04.2016).

Osin, E. N. (2015), 'Alienation from Study as a Predictor of Burnout in University Students: the Role of the Educational Environment Characteristics', Psychological Science and Education, 20 (4), ss. 57-74.

Özbek, M. F. (2011), 'Örgüt İçerisindeki Güven ve İşe Yabancılaşma İlişkisinde Örgüte Uyum Sağlamanın Aracı Rolü', Süleyman Demirel Üniversitesi İktisadi ve İdari Bilimler Fakültesi Dergisi, 16(1), ss. 231-248.

Pearlin, L I. (1962), 'Alienation From Work: A Study of Nursing Personel' American Sociological Review, 27(3), ss. 314-326.

Rabinowitz, K R. (1985), 'Perceptions of Organizational Control and Clinical Social Worker Autonomy: Implications For Conflict, Organizational Alienation and Burnout' Dissertation Abstracts International, 46(3).

Sağlam Arı, G. ve Çına Bal, E. (2008), 'Tükenmişlik Kavramı: Birey ve Örgütler Açısından Önemi' Yönetim ve Ekonomi, 15(1), ss. 131-148.

Seeman, M. (1959), 'On The Meaning of Alienation' Amer. Sociol. Rev., 24, ss. 783-91.

Seeman, M. (1983), 'Alienations Motifs in Comtemporary Theorizing: The Hidden Continuity of The Classic Themes' Social Psychology Quarterly, 46(3), ss. 171184.

Sowmya, K R. ve Panchanatham, N. (2011), Job Burnout: An Outcome of Organisational Politics in Banking Sector' Far East Journal of Psychology and Business, 2(1), ss. 49-58.

Şıklar, E. ve Tunalı, D. (2012), 'Çalışanların Tükenmişlik Düzeylerinin İncelenmesi: Eskişehir Örneği' Dumlupınar Üniversitesi Sosyal Bilimler Dergisi, 33, ss. 75-84. 
Taboli, H. (2015), 'Burnout, Work Engagement, Work Alienation as Predictors of Turnover İntentions among Universities Employees in Kerman', Life Science Journal, 12(9), ss. 67-74.

Tekin, Ö A. (2012), Yabancılaşma ve Beş Faktör Kişilik Özellikleri Arasındaki İlişkiler: Antalya Kemer'deki Beş Yıldızlı Otel İşletmeleri Çalışanları Üzerinde Bir Uygulama, Yayınlanmamıs Doktora Tezi, Akdeniz Üniversitesi, Sosyal Bilimler Enstitüsü, Antalya.

Tomei, G., Casale, T., Tomei, F., Nieto, H. A., Prenna, A., Schifano, M. P. ve Pimpinella, B. (2011). 'Alienation to Burnout. Psyche and the Universe of Technology', Giornaleitaliano di Medicina del Lavoroedergonomia, 34, ss. 400409.

Toprak, E. (2013), Mesleki Tükenmişlik Düzeyi ile İş Tatmini Arasındaki İlişki: Sağlık Sektöründe Bir Araştırma, Yayınlanmamış Yüksek Lisans Tezi, Niğde Üniversitesi, Sosyal Bilimler Enstitüsü, Niğde.

Tuğrul, B. ve Çelik, E. (2002), 'Normal Çocuklarla Çalışan Anaokulu Öğretmelerinde Tükenmişlik' Pamukkale Üniversitesi Eğitim Fakültesi Dergisi, 2 (12), ss. 1-11.

Usul, H. ve Atan, A. (2014), 'Sağlık Sektöründe Yabancılaşma Düzeyi', KMÜ Sosyal ve Ekonomik Araştırmalar Dergisi, 16 (26): ss. 1-10.

Yumuk, Y. (2011), Otel İşletmelerinde İşe Yabancılaşmanın İş Tatmini Üzerine Etkisi: Nevşehir İlinde Bir Uygulama, Yayınlanmamış Yüksek Lisans Tezi, Nevşehir Üniversitesi, Sosyal Bilimler Enstitüsü, Nevşehir. 